NBER WORKING PAPER SERIES

CAN DIRECT AND INDIRECT TAXES BE ADDED FOR INTERNATIONAL COMPARISONS OF COMPETITIVENESS?

Hans - Werner Sinn

Working Paper No. 3263

\author{
NATIONAL BUREAU OF ECONOMIC RESEARCH \\ 1050 Massachusetts Avenue \\ Cambridge, MA 02138 \\ February 1990
}

This paper was prepared for the symposium "Reforming Capital Income Taxation", organized by the Institute of World Economics, Kiel, West Germany, December 1989. This paper is part of NBER's research program in Taxation. Any opinions expressed are those of the author not those of the National Bureau of Economic Research. 


\section{CAN DIRECT AND INDIRECT TAXES BE ADDED FOR INTERNATIONAL COMPARISONS OF COMPETITIVENESS?}

\section{ABSTRACT}

While it is usually argued that direct and indirect taxes should be added for meaningful international comparisons of country competitiveness, this paper argues that the opposite may be true. It is possible that a country with a high value-added tax needs a high capital income tax to maintain its international competitiveness and vice verca. Which view is correct depends on which combination of the origin, destination, source and residence principles prevail and whether or not accelerated depreciation is allowed. Using a Heckscher-Ohlin model with international capital movements the paper studies the relevant alternatives in detail.

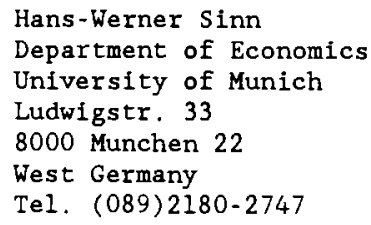


The current world economy seems to be going through a phase of increased tax competition. Corporate and personal income tax rates are being reduced in many countries, and there is growing concern that countries which retain high tax rates will suffer because of increased mobility of goods and factors. European countries in particular are anxious not to lose their competitiveness due to tax-induced capital flight and distortions of trade flows when the barriers fall in 1993.

The public debate on the issue of how taxation affects competitiveness is intense, but confused. Even the most fundamental economic insights seem unlikely to survive in the debate between non-experts.

An obvious sign of confusion is the popular belief that a policy that makes a country attractive for internationally mobile capital will simultaneously improve this country's competitiveness in international trade. Of course, with flexible exchange rates, this cannot be true since the capital import equals the current account deficit. The investors' attempt to import capital will be successful only to the extent that it leads to a revaluation and thereby to a deterioration of the current account. The confusion is shared by countries that take pride in being world export champions without realizing that they could equally well regard themselves as capital flight champions. Economists have warned of such types of irrationality. ${ }^{1}$

A somewhat more subtle, but no less common, mistake in the public policy debate is the focus on measures of aggregate tax burden. It is frequently argued that international

II has been argued by Summers (1986), Masson and Knight (1986), and Sinn (1984, 1985) that the investment incentives introduced in the United States in 1981 have hurt that country's competitiveness and favored Europe's by causing the dollar to appreciate. It is true that capital imports require a positive trade balance in the future to pay for the debt service. However, this long-run effect may not be very relevant for political decisions. With a $2.5 \%$ rate of return to capital it takes 40 years for the debt service to offset the influence on the trade balance of any given flow of capital imports, and in a growing economy where this flow rises at a constant rate, the required time period can be much longer. It seems unlikely that most of those who advocate capital imports to improve a country's competitiveness have the debt service effect in mind. 
comparisons of company tax burdens can reveal meaningful information on the tax influence on competitiveness. Research institutes, political parties, and government publication offices use such comparisons to support their contentions.

Every serious public finance economist is aware, however, how dubious such comparisons are for he knows that a tax burden as such cannot reveal much about the incentive effects of taxation. What matters is how the tax burden reacts to a change in private choice variables, not the burden itself. Some taxes are less distortionary than others, and some have perverse incentive effects. Lump sum taxes are neutral because the revenue they generate is not at all responsive to changes in private behavior, and taxes can be designed whose revenue declines when the activity being taxed increases. With efficient capital markets, the mere size of the tax burden is meaningless for company behavior since the separation theorem excludes all income effects. Only substitution effects matter.

Apart from these general observations, however, the particular knowledge about the effects of the major direct and indirect taxes on international competitiveness is rather limited. It is not at all clear to what extent it makes sense to lump these taxes together for the purpose of international comparisons of competitiveness.

This paper offers some basic insights into the problem by studying conditions for the tax system to exhibit competitive neutrality in a conventional model of international trade and capital movements. The taxes studied are an ideal value-added tax and an income tax with alternative depreciation provisions. Much emphasis is placed on the analysis of alternative combinations of origin, destination, residence, and source principles. The conditions under which the effects of direct and indirect taxes on competitiveness are additive and those under which they are not additive will be distinguished. Interestingly enough, there are a number of combinations under which at least one of the taxes is neutral in the sense that it does not affect a country's competitiveness, and there are two combinations under which a somewhat paradoxical "subtractive neutrality" prevails.

Subtractive neutrality means that direct and indirect taxes have countervailing effects on a country's competitiveness so that, if they are to be taken together at all, the 
respective tax burdens should be subtracted rather than added for meaningful international tax comparisons. It goes without saying that the subtraction is not meant in a strict algebraic sense. It just means that an increase in one domestic tax requires an increase in the other to maintain a country's competitiveness. By way of contrast, the more conventional idea of additive neutrality means that, to preserve neutrality, the increase of one tax must be compensated by a decrease of the other.

Competitive neutrality cannot necessarily be identified with economic efficiency. For the purposes of this paper, it simply means that the tax system does not induce international capital movements and the current account imbalances induced thereby. Competitiveness is a concept that captures what politicians may have in mind when they use this term, but, apart from that, it has little normative content. Indeed, there are many reasons why an extended period of capital imports and reduced competitiveness may be in a country's interest. Even if this is the case, however, it is useful to know the conditions for neutrality, for without them it is difficult to design the tax system in a way that brings about the desired deviation from neutrality.

The question of competitive neutrality of tax systems is by no means new. In Europe, in particular, it is well-known and has frequently been discussed. The interest dates back to the early sixties when France and Germany argued about the appropriate tax treatment of border crossing trade flows. The countries disagreed about the necessity of border adjustments for indirect taxation. France which had high indirect, but low direct, taxes favored the destination principle to protect its own industry against cheap German imports. Germany, on the other hand, favored the origin principle, arguing that the high German direct taxes would compensate for its low indirect taxes. Germany maintained that it would be unfair to burden its exports to France with both the high German direct taxes and the high French indirect ones. As is well-known, France won the case and the destination principle with appropriate border adjustments was implemented.

To clarify the question and presumably to defend the German position, the German Iron and Steel Industry Group ordered a number of scientific reports which were published 
and intensively discussed in the scientific community. ${ }^{2}$ Most experts, who were consulted, implicitly shared the additive neutrality view. They argued that both direct and indirect taxes enter the firms' marginal 'cost schedules and must therefore affect commodity prices and international competitiveness in similar ways. Only one expert (Herbert Timm) rejected the idea of additive neutrality. In his view, direct business taxes resemble rent taxes that cannot be shifted. He agreed with the French position that a border tax adjustment for indirect taxes would bring about tax neutrality and he strongly rejected the idea of additive neutrality. ${ }^{3}$

The problems discussed nearly 30 years ago have become topical again in Europe because the destination principle will be difficult to maintain without border controls. The old claim of the Neumark Committee (1963) that only the origin principle is technically feasible in a fully integrated European market will probably prove to be true after 1992, since a good alternative to the current system of border tax adjustments has not yet been designed. With unhindered cross border shopping, and direct consumer purchases via mail orders or with the aid of a rapidly growing carrying industry, the origin principle will be operative even though the destination principle continues to be prescribed by the tax laws. 4

The solutions reached in the earlier literature are less topical, though, than the problems analyzed. The previous discussion clarified many aspects of the problem, but did not anticipate the results of the current research. It did not pay much attention to international capital movements, did not discuss the role of depreciation allowances, and neglected intersectoral distortions resulting from the fact that the value-added tax is a tax on consumption, but not on investment. 5 Taking up these issues, the present analysis tries

2Overviews and extensions of these reports can be found in Andel (1965) and Sievert (1964). Cf. also the summary of the subsequent literature given by Höhn (1980) and the papers edited by Shoup (1967).

3The Iron and Steel Industry Group prevented Timm's report from being published.

4For a criticism of the proposals of the European Commission see Sinn (1989).

5The same is true of the more recent discussions of the origin and destination principles by Whalley $(1979,1981)$ and Berglas (1981). 
to shed new light on the old problem. It identifies the conditions under which one or the other opinion could possibly be true, and it develops the case of subtractive neutrality which, 30 years ago, would have raised eyebrows even more than today.

In Section 2 of the paper, a formal framework for the discussion is specified and a definition for tax neutrality is given. Section 3 analyzes the borderline cases between additive and subtractive neutrality where at least one of the taxes has a lump sum characteristic and so does not affect a country's competitiveness. Section 4 discusses the conditions for additive and subtractive neutrality, and Section 5 offers a conclusion.

\section{A Framework for a Comparison}

As a framework for a comparison of tax effects on a country's competitiveness the conventional two country, two commodity, two factor Heckscher-Ohlin model is used where, however, capital movements are allowed. In the absence of taxation, the model predicts equal factor prices and thus the possibility of capital movements is unimportant. As capital earns the same rate of return everywhere when there is no perfect specialization, international capital flows are indeterminate. Even if capital moves, the rates of return it can earn in the two countries will not be affected. Because of the Rybczynski effect, an increase in one country's capital stock will simply be absorbed by a growth of the capital intensive sector at the expense of the labor intensive sector with no change in either sector's own capital intensity.

Suppose, however, distortionary taxes are introduced that drive wedges between the national rates of return to capital, either directly by taxing these rates of return or indirectly by taxing the commodity flows and changing factor demands. Under these circumstances, very large capital movements will take place, large enough to drive at least one of the countries into perfect specialization. An interior equilibrium where both countries produce both commodities is impossible with distortionary taxation for, in the 
Heckscher-Ohlin model, there is a horizontal demand curve for capital when both commodities are produced. 6

To be sure, the neglect of fixed factors of production in the Heckscher-Ohlin model overstates the tax distortions. However, the main focus of this paper is not on the size of distortions, but on conditions for tax neutrality. The very fact of its sensitivity to tax differentials makes the Heckscher-Ohlin model ideally suited for this task. Following the definition given in the introduction, the tax systems of the two countries are said to be neutral with regard to international competitiveness if, despite taxation, no reallocation of the given world capital stock is induced and both countries continue to produce both commodities.

It is true that, in addition to changing the allocation of the world capital stock, taxation can affect a country's competitiveness also by changing its flow of savings. For example, a tax cut that stimulates domestic savings may induce capital exports and thus improve this country's competitiveness via a devaluation. However, the present paper neglects this possibility. Apart from the fact that a reallocation of a capital stock is capable of generating larger capital movements than a reallocation of its increments, the concentration on neutrality conditions for stock adjustments is legitimated by the Rybczynski effect. It will take many years before a change in savings will have generated a change in the stock of capital large enough to drive a country into perfect specialization, and before this has happened, the change in savings can neither induce international capital movements nor affect a country's competitiveness. Of course, these aspects of the model cannot literally be applied to an existing economy, but they clarify why international stock adjustments may be the dominant channel through which tax reforms affect a country's competitiveness.

Let France $(F)$ and Germany $(G)$ be the two countries considered and assume that the commodities produced and traded are a homogeneous investment good (I) and a

${ }^{6}$ This is a well-known phenomenon in the theory of foreign trade. Cf. Kemp (1969, Ch. 9). 
homogeneous consumption good $(C)$. As usual, the countries have identical technological knowledge. Production of sector $i$ in country $j$ is determined by the linearly homogenous, well-behaved function $f_{i}\left(K_{i}^{j}, L_{i}^{j}\right) ; j=F, G ; i=C, I$; the arguments of which are capital $(K)$ and labor $(L)$. Capital and output are fully mobile, labor is only mobile within each country. The aggregate stocks of labor and capital are exogenously given: $K=K_{C}^{F}+K_{I}^{F}+K_{C}^{G}+K_{I}^{G}=$ const., $L^{F}=L_{C}^{F}+L_{I}^{F}=$ const., $L^{G}=L_{C}^{G}+L_{I}^{G}=$ const. All prices are expressed in terms of money or gold and assumed to be constant over time because the economies have settled to a stationary equilibrium. The producer prices of the four outputs are denoted by $P_{i}^{j} ; j=F, G ; i=C, I$; and the marginal pre-tax rates of ret urn to capital in the four sectors are given by

$$
R_{i}^{j} \equiv \frac{\partial f_{i}}{\partial K_{i}^{j}} \cdot \frac{P_{i}^{j}}{P_{I}^{j}} ; j=F, G ; i=C, I
$$

Accordingly,

$$
W_{i}^{j} \equiv \frac{\partial f_{i}}{\partial L_{i}^{j}} \cdot \frac{P_{i}^{j}}{P_{I}^{j}} ; j=F, G ; i=C, I ;
$$

are the sector-specific marginal value products of labor in terms of the respective national investment good.

Assuming a competitive equilibrium and equal tax treatments of all sectors within an economy, there will be a unique pre-tax return to capital in each country:

$$
R^{j}=R_{C}^{j}=R_{I}^{j} \text { for } j=F, G
$$

and a unique marginal value product of labor: 


$$
W^{j}=W_{C}^{j}=W_{I}^{j} \text { for } j=F, G
$$

Since no labor taxes are considered in the present paper, the latter can be identified with the respective national real wage rates. By way of contrast, capital income taxation implies that $R^{j}$ is not necessarily equal to country $j$ 's national pre-tax rate of interest; the separate variable $r^{j}, j=F, G$, is therefore reserved for this rate.

The crucial relationship in the model is that between the commodity and factor prices. Because of the linear homogeneity assumption, it follows from (1)-(4) that the factor price ratio $R^{j} / W^{j}$ uniquely determins the absolute level of the domestic pre-tax rate of return to capital, $R^{j}=\partial f_{I} / \partial K_{I}^{j}, j=F, G$, and the producer price of consumption goods in terms of investment goods (or rate of commodity transformation): $P_{C}^{j} / P_{I}^{j}=\left(\partial f_{I} / \partial L_{I}^{j}\right) /\left(\partial f_{C} / \partial L_{C}^{j}\right)=\left(\partial f_{I} / \partial K_{I}^{j}\right) /\left(\partial f_{C} / \partial K_{C}^{j}\right), j=F, G$. If it is assumed that the sectors exhibit different and non-reversing capital intensities: $k_{I}^{j}>k_{C}^{j}$ or $k_{I}^{j}<k_{C}^{j} \forall R^{j} / W^{j}, k_{i}^{j} \equiv K_{i}^{j} / L_{i}^{j} ; j=F, G ; i=C, I$, then the relationship between the pre-tax rate of return to capital, $R^{j}$, and the producer price of consumption goods in terms of investment goods, $P_{C}^{j} / P_{I}^{j}$, is monotone and unique, independent of the national factor endowments. This is the well-known Stolper-Samuelson result.

Figure 1 illustrates the case where $k_{I}^{j}>k_{C}^{j}$ for all possible factor price ratios. The two heavy lines in the right part of the diagram are marginal product curves which depict the relationships between the sectoral factor intensities and the pre-tax rate of return to capital, and the heavy line in the left part shows the relationship between the latter and the producer price of consumption goods in terms of investment goods. The higher this price, the more consumption goods are produced and the lower is the rate of return to capital, which is the more abundant factor of production in the consumption goods industry. If, alternatively, $k_{C}^{j}>k_{I}^{j}$ for all $R^{j} / W^{j}$ is assumed, then there is a positive relationship between $R^{j}$ and $P_{C}^{j} / P_{I}^{j}$ : a higher relative price of consumption goods and more output in the consumption goods industry in this case implies a higher relative 
scarcity of, and hence a higher rate of return to, capital. To summarize,

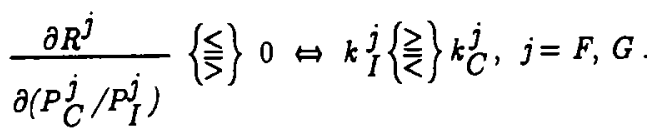

Figure 1: The Producer Price of Consumption Goods and the Pre-tax Rate of Return to Capital $\left(k k_{I}^{j}>k_{C}^{j} \forall R^{j} / W^{j}\right)$

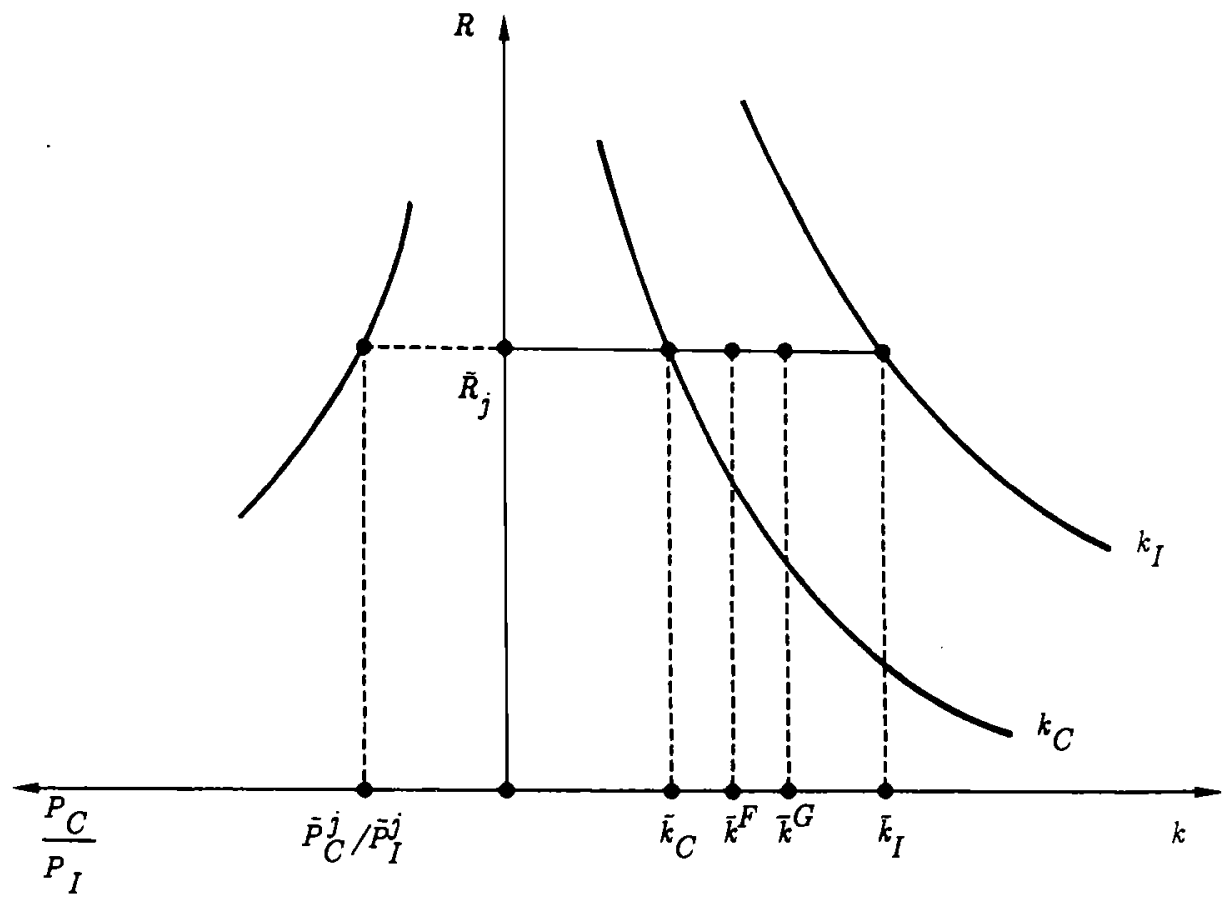

A special solution that illustrates the relationship between the commodity and factor prices is indicated by tildes in Figure 1 . The solution makes it clear that a given set of factor and commodity prices uniquely determins the sectoral capital intensities, but not 
the average capital intensities $k^{G}$ and $k^{F}$ in the two countries. Any reallocation of the world capital stock $K$ is compatible with the solution as long as $k_{C} \leq k^{j} \leq k_{I}, j=F, G$.

\section{The Role of Taxation}

In the absence of taxation, trade equalizes the commodity price ratios, $P_{C}^{F} / P_{I}^{F}=P_{C}^{G} / P_{I}^{G}$, and the Heckscher-Ohlin mechanism described equalizes the rates of return to capital: $R^{F}=R^{G}$. The latter equality does not result from free capital movements, but it harmonizes perfectly well with such movements.

Taxes drive wedges between the commodity and factor prices and thus can severely distort this equilibrium. ${ }^{7}$ This paper considers value-added and capital income taxes. It is assumed that the rates of these taxes are uniform within a country, but not necessarily between countries.

The value-added tax is of the European type. It is a $\operatorname{tax}$ on consumption which exempts investment goods. Let $\tau^{F}$ and $\tau^{G}$ be the French and German tax rates.

The capital income tax is a variant of the Schanz-Haig-Simons tax. It applies to all kinds of capital incomes including personal interest income, retained profits, and distributed profits, and it is therefore neutral with regard to the firms' financial decisions. Double taxation of corporate dividends could be allowed without changing the results provided that debt and retained profits are sufficient to satisfy the firms' need for funds. The respective national capital income tax rates are denoted by $t^{F}$ and $t^{G}$.

The model deviates from the Schanz-Haig-Simons requirements by allowing tax depreciation to differ from true economic depreciation. Actual deviations from true economic depreciation have been so dramatic in recent years that this important aspect should not be neglected. It is assumed that country $j$ allows the proportion $\alpha^{j}$ of gross

7The paper neglects distortions that may arise from international differences in the production of public goods, an aspect emphasized by Möller (1968). 
investment to be written off immediately, while the proportion $1-\alpha^{j}$ is written off gradually over time, in strict proportion with true economic depreciation. With $\alpha^{j}=1$, the capital income tax is a pure Schanz-Haig-Simons tax, with $\alpha^{j}=1$ it is a variant of a cash flow tax where debt interest remains deductible.

Apart from the national tax codes, it is important to specify the tax treatment of border crossing commodity and interest income flows. Four taxation principles are distinguished and checked for their implications for commodity and capital market equilibria.

\subsection{Commodity Market Equilibrium}

As investment commodities are untaxed, it can invariably be assumed that trade equates their prices:

$$
P_{I}^{F}=P_{I}^{G}
$$

(all systems).

However, for consumption goods two alternatives will be considered. Under the destination principle which is currently in use in Europe, and is also recommended by the GATT, French consumers are indifferent between domestic and foreign goods when $P_{C}^{F}\left(1+\tau^{F}\right)=P_{C}^{G}\left(1+\tau^{F}\right)$, and German consumers are indifferent when $P_{C}^{F}\left(1+\tau^{G}\right)$ $=P_{C}^{G}\left(1+\tau^{G}\right)$. Obviously, the tax rates cancel out, and there is an equilibrium in consumption goods markets if the national producer prices are equated:

$$
P_{C}^{F}=P_{C}^{G} \quad \text { (destination principle) }
$$

By way of contrast, the origin principle which in all likelihood will characterize post-1992 Europe, makes consumers from both countries indifferent between French and 
German consumption goods when the tax inclusive prices are equal:

$$
P_{C}^{F}\left(1+\tau^{F}\right)=P_{C}^{G}\left(1+\tau^{G}\right) \quad \text { (origin principle) }
$$

\subsection{Capital Market Equilibrium}

Unlike the equilibrium in the commodity market, equilibrium in the capital market is characterized by two types of equation. The first describes a single firm's optimal investment strategy.

With true economic depreciation, the Johansson-Samuelson theorem would ensure that firms invest up to the point where the pre-tax rate of return to capital, $R^{j}$ [from (3)], is equated with the national market rate of interest, $r^{j}, j=F, G$. There is a partial analytic investment neutrality, since the income tax burdens the returns from real investment in the same way as the returns from a financial capital market investment. If an immediate write-off of real investment expenses were allowed, firms would equate their pre-tax rate of return to the net of tax market rate of interest, $R^{j}=\left(1-t^{j}\right) r^{j}$. In general, the firms' optimal investment condition is: 8

$$
R^{j}=\left(1-\alpha^{j}{ }^{j}\right)_{r}^{j}, j=F, G
$$

where $\alpha$ is the depreciation parameter introduced above $\left(0 \leq \alpha^{j} \leq 1\right)$.

The second equation relates the national interest rates via international arbitrage. $\theta$ Under the residence principle for interest income taxation which is postulated in the OECD

sFor a derivation of this formula from an explicit intertemporal optimization model of the firm see Sinn (1987).

-Discussions of the implications of residence and source principles for international capital movements can be found in Grubert and Mutti (1985), Slemrod (1988), and Sinn (1984a,
1984b). 
Model Double Taxation Convention of 1977 and legally installed by most countries, interest income is taxed in the investor's home country. The German investor is therefore indifferent between French and German investment if $r^{F}\left(1-t{ }^{G}\right)=r G(1-t)$, and the French investor is indifferent if $r^{F}\left(1-t^{F}\right)=r^{G}\left(1-t^{F}\right)$. Obviously, the terms in brackets cancel out, and a capital market equilibrium prevails if

$$
r^{F}=r^{G} \quad \text { (residence principle). }
$$

As in the absence of taxation, arbitrage equates the pre-tax interest rate across the borders.

The alternative to the residence principle is the source principle. The source principle is technically easier to implement, but, as the German failure to introduce such a tax in 1989 showed, it induces strong international capital movements. Under the source principle investors are indifferent between French and German assets if the interest rates net of the national capital income taxes are the same:

$$
{ }^{F}\left(1-t^{F}\right)=r^{G}\left(1-t^{G}\right) \quad \text { (source principle). }
$$

Different assumptions on depreciation allowances, different principles for border crossing interest income and commodity flows, and different assumptions on the capital intensities of the consumption and investment goods industries yield a considerable variety of $\operatorname{tax}$ worlds. The alternatives are summarized in Table 1 which serves as a guideline for the subsequent discussion of neutral tax policies.

\section{Robust Neutrality}

The discussion of neutral tax policies begins with what may be called "robust neutrality". 
Robust neutrality means that a country can freely choose a tax rate without affecting its international competitiveness. The capital income tax can exhibit robust neutrality, the value-added $\operatorname{tax}$ can have it, and they may both have it together. Robust neutrality is the borderline case between additive and subtractive neutrality as defined in the introduction.

From (6), (7), (9), and (10) it is obvious that the combination of the destination principle, true economic depreciation $(\alpha=0)$, and the residence principle will ensure robust neutrality for both taxes. As in the laissez faire case producer prices of consumption goods in terms of investment goods are the same in both countries,

$$
\frac{P_{C}^{F}}{P_{I}^{F}}=\frac{P_{C}^{G}}{P_{I}^{G}}
$$

and pre-tax rates of return to capital are also the same:

$$
R^{F}=R^{G}
$$

Clearly it remains possible that both countries produce both goods. Note that (12) and (13) are not only neutrality but also efficiency conditions. They ensure that, given their aggregate factor endowments, the two countries operate on their joint efficiency frontier. The next section will analyze neutrality conditions which do not coincide with efficiency conditions. 
Table 1:

Neutrality Conditions

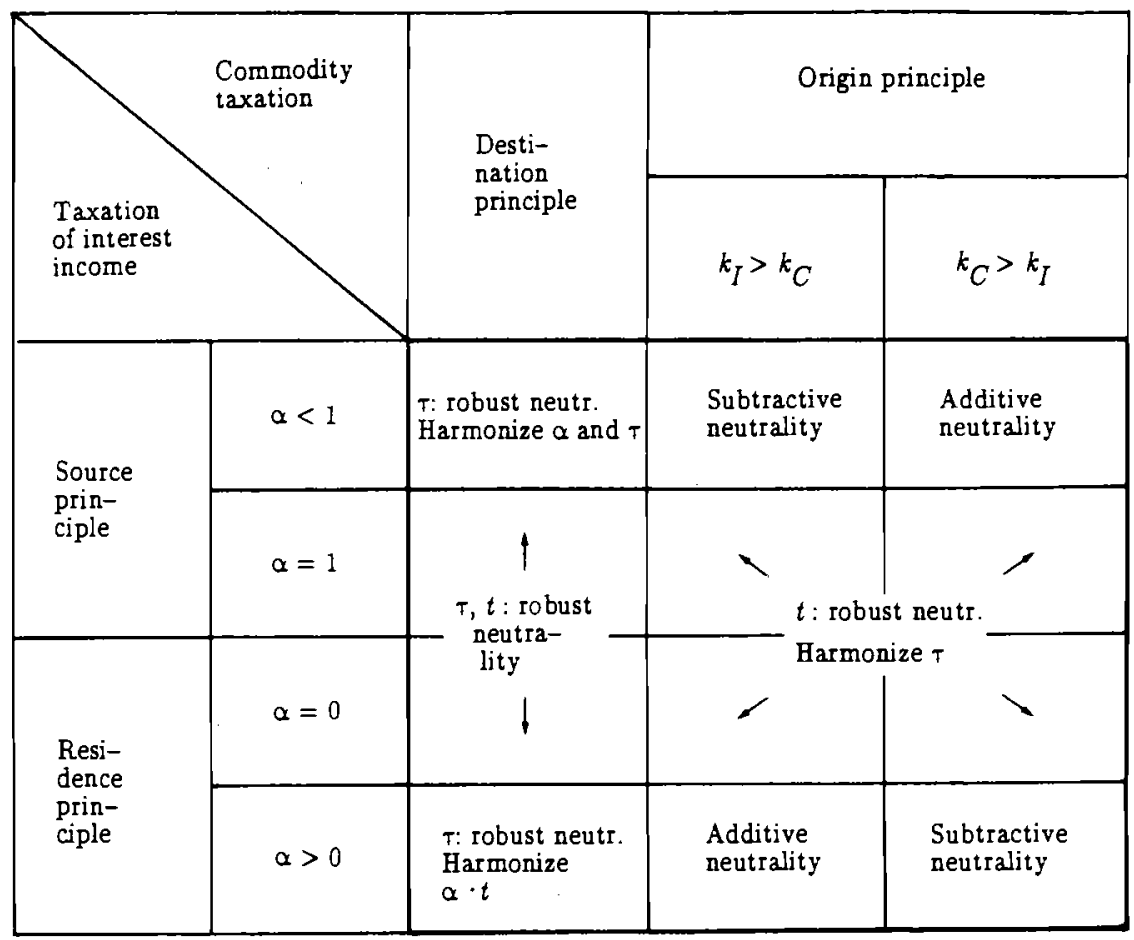

The case considered is represented in the third field of the first column of Table 1. It can be seen as the ideal legal combination recommended by the GATT, the OECD Model Double Taxation Convention and the Schanz-Haig-Simons income definition. Interestingly enough, even this case strongly contradicts the view that aggregate tax burden comparisons matter for a country's international competitiveness. Contrary to that view, each country is able to choose its capital income tax and value-added tax rates freely without changing its competitiveness.

An equally robust neutrality case is described by the second field in the first column 
of Table 1. When the destination principle is maintained, but the source principle and immediate depreciation $(\alpha=1)$ are chosen, then (12) and (13) will again be true. The latter equation follows from equation (9) with $\alpha=1$ and from equation (11). Equation (9) says that firms invest up to the point where their pre-tax rate of return to capital equals the net of tax market rate of interest, and equation (11) says that international arbitrage equates the national interest rates net of the respective national tax rates. This tax world was analyzed by $\operatorname{Sinn}(1987$, ch. 11) and recommended as a feasible alternative to the idea underlying the existing tax world which was rejected as theoretically unattractive and practically not feasible. 10

It should perhaps be noted that the assumption of an immediate write-off, which characterizes the present case, is not as remote as it might seem at first sight. In fact, it characterizes almost perfectly the situation in the Reagan era in the United States. Official estimates by the Office of Tax Analysis in the Treasury Department confirmed that, in the period from 1981 to 1986 , the United States had investment incentives that resembled and even exceeded an immediate write-off. i1 Mind though that the United States and its trading partners continued to apply the residence principle. As can be seen from (9) and (10), this policy constellation was strongly non-neutral, creating incentives for capital imports that, in the Heckscher-Ohlin model of Section 2, would have wiped out capital intensive sectors in the rest of the world and/or labor intensive sectors in the U.S. ${ }^{12}$

To avoid these consequences of accelerated tax depreciation without sacrificing the destination and residence principles, it would have been necessary to harmonize the capital income tax rates and depreciation allowances across countries in a way that equated the

${ }^{10}$ The main reasons for recommending the alternative tax system were its administrative advantages and its intertemporal neutrality properties.

"See U.S. Department of the Treasury (1984, pp. 106, 107, and 112). Cf. also Gravelle (1982) and Fullerton, Gilette, and Mackie (1987, p. 144, Table 5.4).

${ }^{12}$ An analysis of the 1981 U.S. tax reform in a Heckscher-Ohlin model is provided in Sinn (1984b, pp. 568-572). Cf. Krause-Junk (1988) for a welfare analysis of accelerated depreciation in an open economy. 
national values for the term $\alpha$. This can be seen from equations (9) and (10) which show how the pre-tax rates of return to capital are related in a capital market equilibrium:

$$
\frac{R^{F}}{1-\alpha^{F} F}=\frac{R^{G}}{1-\alpha^{G G}} \quad \text { (residence principle). }
$$

Obviously $R^{F}=R^{G}$ if, and only if, $\alpha^{F} F=\alpha_{t} G$.

The property of robust neutrality applies only partially under these circumstances; it is maintained for the value-added tax, but not for the capital income tax. Nevertheless, it remains true that a simple summation of the national tax burdens reveals almost nothing about the influence of taxes on international competitiveness. The case is illustrated by the last field in the first column of Table 1.

A related case is the first field in this column where the source principle applies, but immediate depreciation is not allowed. Again, the destination principle ensures robust neutrality for the value-added tax. However, to equate the national pre-tax rates of return to capital, it is not sufficient to harmonize the term $\alpha$ t. Equations (9) and (11) imply that

$$
R^{F} \frac{1-t^{F}}{1-\alpha^{F} F}=R^{G} \frac{1-t^{G}}{1-\alpha^{G} G} \quad \text { (source principle). }
$$

This shows that for $R^{F}=R^{G}$ it is necessary to harmonize both the tax rates and the depreciation allowances.

Consider now a replacement of the destination with the origin principle, the policy advocated by the German Iron and Steel Industry. Regardless of whether the residence principle and true economic depreciation $(\alpha=0)$ or the source principle and free depreciation $(\alpha=1)$ prevail, it will remain true that the equilibrium in the international capital market is characterized by $R^{F}=R^{G}$. Direct taxation continues to enjoy robust neutrality. However, as shown by (6) and (8), only a harmonization of the national 
value-added tax rates can prevent a distortion by ensuring that $P_{C}^{G} / P_{I}^{G}=P_{C}^{F} / P_{I}^{F}$. In the table, these are the second and third fields in the second and third columns.

When the French exceeds the German value-added tax rate $\left(\tau^{F}>\tau^{G}\right)$ as in the historical case, it follows from (6) and (8) that the German producer price of consumption goods in terms of investment goods exceeds its French counterpart: $P_{C}^{G} / P_{I}^{G}>P_{C}^{F} / P_{I}^{F}$. Because of the Stolper-Samuelson result (5), this demands a wedge between the pre-tax rates of return to capital even though a wedge is excluded in the assumed system of direct taxation. Perfect specialization and a dramatic change of international competitiveness results regardless of whether the overall tax burden imposed on French and German firms is the same. This provides a strong support for the French position that the origin principle would be non-neutral without a harmonization of value-added tax rates.

It is frequently argued that different value-added tax rates are harmless even with the origin principle since mere exchange rate adjustments are sufficient to neutralize the tax rate differences. ${ }^{13}$ In the case of France and Germany, for example, a revaluation of German currency is expected to fully compensate for the lower value-added tax rate. This view certainly cannot be confirmed with the model used in this paper even though it is a model of pure exchange that implicitly assumes full exchange rate flexibility. The reason for the fallacy of the exchange rate argument is that it neglects the fact that even an ideal value-added tax of European type is not a uniform tax on all commodities: it is a pure consumption tax that exempts investment goods. It is impossible for exchange rate adjustments to compensate for tax-induced changes in relative prices. The revaluation of German currency (or the inflation) that would have occurred had the origin principle been introduced in the sixties and that will probably occur after 1992 when direct consumer purchases will enforce the origin principle in Europe undoubtedly hurts the German investment goods industry. There is a reallocation of productive factors from this industry

13The argument dates back to the Tinbergen Committee (1953) which referred to a uniform indirect tax, not a value-added tax. 
to the German consumption goods industry, and the French investment goods industry gains at the expense of the French consumption goods industry. ${ }^{14}$

\section{Additive and Subtractive Neutrality}

The model offers a number of options for preventing excessive international capital movements from eliminating the German investment goods industry and/or the French consumption goods industry. When the origin principle with non-harmonized value-added tax rates applies, only one option is left. It is necessary to deviate from neutrality in the taxation of border crossing interest income flows to create a tax distortion in capital markets that just compensates for the tax distortion in goods markets. Via sectoral shifts, the distortion in goods markets translates into a gap between the national pre-tax rates of return to capital, $R^{F}-R^{G}$. The distortion in the capital market must therefore be designed in a way that makes this gap compatible with a capital market equilibrium.

The required compensating distortion in the capital market can, in principle, be achieved either by not combining the source principle with instantaneous depreciation or by not combining the residence principle with true economic depreciation, and its direction depends on which sector is more capital intensive. There are thus four possible cases. They are represented by the first and fourth fields of the third and fourth columns of Table 1.

Suppose first that the investment goods industry is more capital intensive than the consumption goods industry: $k_{I}^{j}>k_{C}^{j}$ for $j=F, G$ and all relevant factor price ratios. In this case, it follows from (5) that the commodity price distortion $P_{C}^{G} / P_{I}^{G}>P_{C}^{F} / P_{I}^{F}$ which (6) and (8) imply for the case of a comparatively low German value-added tax rate $\left(\tau^{G}<\tau^{F}\right)$ results in an excess of the French over the German pre-tax return to capital: $R^{F}>R^{G}$. Other things being equal, the high-tax country attracts the capital. To compensate for this attraction a comparatively high source tax on French interest income

14This criticism of the exchange rate argument is also made in Sinn (1989). 
$\left(t^{F}>t^{G}\right)$ and/or more restrictive depreciation allowances than in Germany $\left(\alpha^{F}<\alpha^{G}\right)$ are required. Equation (15) shows that both measures make a capital market equilibrium with $\left(R^{F}>R^{G}\right)$ possible and prevent the countries from being driven into perfect specialisation.

This paradoxical case is an example of what in the introduction was called subtractive neutrality. The country with the higher value-added tax needs a higher capital income tax to maintain its competitiveness. The result stands the conventional additive neutrality view on its head.

Other, even more paradoxical, options for preventing the high French value-added tax from attracting capital from Germany exist under the residence principle. It remains true that, as with the source principle, comparatively restrictive depreciation allowances in Germany will do the job. However with given and identical accelerated depreciation allowances in the two countries $\left(\alpha^{G}=\alpha^{F}>0\right.$ ) it would also be possible to keep the capital in Germany by implementing comparatively higher capital income tax rates. Equation (14), the capital market equilibrium condition for the residence principle, shows this very clearly: when $\alpha^{F}=\alpha^{G}$, an equilibrium with $R^{F}>R^{G}$ can occur if, and only if, $t^{G}>t^{F}$. The mechanism operating here is the by now well-known taxation paradox. ${ }^{15}$ Its essence is that, with accelerated depreciation and the residence principle, an increase in the national tax rate punishes real domestic investment less than financial investment abroad. Investors have therefore an incentive to invest in the country with the higher capital income tax rate, and this incentive may just compensate for the higher pre-tax return that lures the capital from abroad.

The result of all this is, as is indicated in the last field in the second column of Table 1, additive neutrality. A country with a high value-added tax needs a low capital income tax to maintain its international competitiveness, and vice versa. A conventional belief is confirmed. It must be stressed, however, that in this case the conventional belief is

${ }^{15}$ Cf. Sinn (1987, Chapter 5.4.3). 
right for the wrong reason. It is not true that a high value-added tax rate deters the capital and a low capital income tax rate is needed to attract it again. On the contrary, in the case considered, a low value-added tax deters the capital and high capital income tax rate is needed to attract it. The conventional belief is confirmed because two paradoxes offset one another.

Fortunately, there is a case where the conventional view is confirmed. It is represented by the first field in the third column of Table 1 . If the consumption goods sector is more capital intensive than the investment goods sector, then the country with the lower value-added tax rate can offer a higher pre-tax rate of return to capital. Formally, if $k_{C}^{j}>k_{I}^{j}$ for $j=F, G$ and all relevant factor price ratios, and if $\tau^{G}>\tau^{F}$, then it follows from (5), (6), and (8) that $P_{C}^{G} / P_{I}^{G}>P_{C}^{F} / P_{I}^{F}$ and $R^{G}>R^{F}$. Under the source principle without immediate write off $(\alpha<1)$ it is possible to compensate for this and to stop the drive towards perfect specialization that otherwise would occur by accompanying the low value-added tax rate with a high capital income tax rate and/or restrictive depreciation allowances. This is obvious by again inspecting equation (15). The case considered should be the one which those who focus on aggregate tax burden comparisons have in mind. At last, there is a combination where they are right for the right reason. There are no paradoxes and additive neutrality prevails.

Unfortunately, there is insufficient empirical evidence to ultimately decide which of the two sectors is the more capital intensive. In two-sector models of economic growth with Keynesian savings functions it is usually necessary to assume that the consumption goods sector is more capital intensive because otherwise the growth path would not be stable. ${ }^{16}$ However, there is no good reason for applying the correspondence principle across theoretical models, let alone for using Keynesian stability conditions to predict the outcome of neoclassical allocation models. More intriguing evidence comes from a study on Germany by Wallwein (1986). This study confirms the assumption that the consumption

16See Shinkai (1960) and Uzawa (1962). 
goods sector is more capital intensive, although no attempt is made to explain the empirical significance of the results that are offered. An earlier study by Sutton (1976) finds the evidence in favor of the stability case less convincing.

Should the consumption goods sector really turn out to be more capital intensive than the capital goods sector, then the application of the source principle for the taxation of border crossing interest income flows will ensure that the conventional additive neutrality view does have its merits. It must not be forgotten though that the source principle is just a theoretical possibility. As mentioned earlier, the residence principle is the principle most widely used among OECD countries. Moreover, accelerated depreciation is the relevant assumption for most countries. Under these circumstances, the taxation paradox applies and is not counterbalanced by the value-added tax paradox studied above. A low value-added tax rate expands the capital intensive sector and attracts capital imports. To compensate for this attraction and to prevent the countries from being driven into perfect specialization, the capital income tax rate must also be low. The case is represented by the last field in the last column of Table 1. Again, the tax system exhibits the property of subtractive neutrality. Perhaps this is the most plausible case of all.

\section{Concluding Remarks}

The preceding analysis is a study in the effects of taxation on international competitiveness with particular emphasis on neutrality conditions. Focusing on ideal versions of the value-added tax and ideal versions of a capital income tax, it demonstrated the general invalidity of the common claim that the tax influence on a country's competitiveness can be assessed by measuring the aggregate company tax burden. Various conditions for "robust neutrality" and "subtractive neutrality" were isolated, under which the conventional claim is completely unjustified. The conclusion is that it may well be the case that direct and indirect taxes counteract each other so that a country that has a high 
value-added tax rate needs a high capital income tax rate as well if it wants to preserve its international competitiveness.

The analysis was confined to two single model taxes, albeit with a variety of modifications. More institutional detail should be and can be introduced at a later stage. For example, it would be useful to allow for diverging tax rates on interest income and retained profits, to introduce capital gains taxation, and to consider alternative indirect taxes and subsidies. The basic interaction possibilities between indirect and direct taxation that were pointed our in this paper, including the effects operating through changes in sectoral structures and pre-tax factor prices, are likely to survive this generalization.

The paper is neither a normative nor an empirical study. It is an attempt to develop a systematic framework for international tax comparisons and policy recommendations, and it makes predictions of the effects of alternative tax systems on international competitiveness. Hopefully, this framework will in the future turn out to be useful for more applied work, including that of research institutes which specialize in the field of world economics. 


\section{References}

Andel, N. (1965): "Zur Diskussion 'Ursprungs-' versus 'Bestimmungslandprinzip'", Finanzarchiv 24, S. 115-123.

Berglas, E. (1981): "Harmonization of Commodity Taxes", Journal of Public Economics 16, 377-387.

Gravelle, J.G. (1982): "Effects of the 1981 Depreciation Revisions on the Taxation of Income from Business Capital", National Tax Journal 35, 1-20.

Fullerton, D., R. Gilette, and J. Mackie (1987): "Investment Allocation and Growth Under the Tax Reform Act of 1986", in: Office of Tax Analysis (ed.), Compendium of Tax Research 1987, Washington, D.C.: U.S. Government Printing Office.

Höhn, M. (1980): Zur Diskussion 'Mehrwertsteuer versus Körperschaftsteuer', Bochum.

Kemp, M.C. (1969): The Pure Theory of International Trade and Investment, Englewood Cliffs: Prentice Hall.

Krause-Junk, G. (1988): "Außenwirtschaftliche Konsequenzen beschleunigter Abschreibung", Finanzarchiv 46, 252-267.

Masson, P.R., and M. Knight (1986): "The International Transmission of Fiscal Policies in Major Industrial Countries", IMF Staff Papers 33, 378-438.

Mutti, J., and H. Grubert (1985): "The Taxation of Capital Income in an Open Economy: The Importance of Resident-Nonresident Tax Treatment", Jourmal of Public Economics 27, 291-309.

Shinkai, Y. (1960): "On Equilibrium Growth of Capital and Labor", International Economic Review 1, 107-111.

Shoup, C.S. (1967): Fiscal Harmonization in Common Markets, Bd. I (Hrsg. Shoup), New York und London.

Sievert, O. (1964): Außenwirtschaftiche Probleme steuerlicher Ausgleichsmaßnahmen für den internationalen Handel, Köln, Berlin, Bonn and München: Carl Heymanns Verlag $\mathrm{KG}$.

Sinn, H.-W. (1984a): "Systeme der Kapitaleinkommensbesteuerung. Ein allokationstheoretischer Vergleich", in: D. Bös, M. Rose, and Ch. Seidl (eds.), Beitrage zur neueren Steuertheorie, Berlin and Heidelberg: Springer Verlag, 209-238.

- (1984b): "Die Bedeutung des Accelerated Cost Recovery System für den internationalen Kapitalverkehr", Kyklos 37, 542-576.

(1985): "Why Taxes Matter: Reagan's Accelerated Cost Recovery System and the U.S. Trade Deficit", Economic Policy 1, 239-347.

- (1987): Capital Income Taxation and Resource Allocation, Amsterdam, New York, Oxford and Tokio: North Holland Publishing Company.

--, (1989): "Tax Harmonization and Tax Competition in Europe", forthcoming in: European Economic Review, Papers \& proceedings, and NBER discussion paper
series.

Slemrod, J. (1988): "Effect of Taxation with International Capital Mobility", in: H.J. Aaron, H. Galper, and J. Pechman, eds., Uneasy Compromise. Problems of a Hybrid Income-Consumption Tax, Washington D.C.: Bookings Institution. 
Summers, L.H. (1986): "Tax Policy and International Competitiveness", Harvard Institute of Economic Research, Discussion paper No. 1256.

Sutton, J. (1976): "The Relativ Factor Intensities of Investment and Consumer Goods Industries: A Note", Econometrica 44, 819-821.

Uzawa, H. (1962): "On a Two-Sector Model of Economic Growth", Review of Economic Studies 29, 40-47.

Wallwein, E. (1986): Die Bedeutung der Kapitalintensitatshypothese im neoklassischen Zwei-Sektoren Modell und ihre empirische Uberprifung, Frankfurt, Bern, and New York: Peter Lang.

Whalley, J. (1979): "Uniform Domestic Taxes, Trade Distortions, and Economic Integration", Journal of Public Economics 11, 213-221. --, (1981): "Border Adjustments and Tax Harmonization: Comment on Berglas",
Joumal of Public Economics 16, 389-390.

Reports

Neumark Committee (1963): Report of the Fiscal and Financial Committee, The EEC Reports on Tax Harmonization (International Bureau of Fiscal Documentation).

Tinbergen Committee (1953): Report on Problems Raised by the Different Turnover Tax Systems Applied within the Common Market.

OECD (1977): Model Double Taxation Convention on Income and on Capital. Report of the OECD Committee on Fiscal Affairs, Paris.

U.S. Department of the Treasury (1984): Tax Reforms for Faimess, Simplicity, and Economic Growth, Washington: U.S. Government Printing Office. 